\title{
PENGAWASAN TERHADAP SYARAT UMUM DAN KHUSUS DALAM PELAKSANAAN PIDANA BERSYARAT
}

\section{Niken Subekti Budi Utami}

\begin{abstract}
The probation is an alternative conditional independence revocation entity that is intended to avoid some negative impact from the implementation of the criminal in prison. Implementation of probation committed outside the correctional institution with provisions for prisoners on probation must abide by conditions set by the judge requirements to be supervised by a supervisory officer.

The purpose of this study is to investigate the implementation of the supervision of general and specific requirements by the supervisory officer in this case conducted by the supervisory judge observer (kimwasmat), prosecutors and Correctional Center (BAPAS).

This research was conducted with library research to obtain secondary data and field research to obtain primary data.

In conducting surveillance, kimwasmat never touched prisoner probation supervision, citing a judge's limited ability to perform tasks supervisory oversight of all court decisions, in addition to the obstruction of funding is not budgeted specifically for the task. Supervision conducted by the prosecutor is also not running, because prosecutors had handed over control to BAPAS. The supervision by BAPAS is precisely the effective control, because it is done with two-way method, which offenders are required to report to the office of BAPAS for any particular period and given guidance in the form of mental training and skills. Supervising social each month, also visited a client's home with intent to know the development of coaching.
\end{abstract}

Based on data obtained from BAPAS Yogyakarta during the last year and a half, never breach the terms of which the judge determined, so it can be said implementation of the supervision and coaching successful.

Keywords: supervision, probation, general and special requirements. 


\section{A. Pendahuluan}

Dalam rangka mempertahankan dan menyelenggarakan ketertiban masyarakat, negara berhak menjatuhkan pidana terhadap pelaku perbuatan pidana. Menurut Sudarto, yang dikutip Barda Nawawi, pidana merupakan suatu penderitaan atau nestapa yang ditimpakan kepada seseorang yang melakukan perbuatan dan telah memenuhi persyaratan tertentu (Muladi dan Barda Nawawi Arief. 1998: 28). Sedangkan menurut Roeslan Saleh, pidana merupakan reaksi atas delik dan berujud suatu nestapa yang sengaja ditimpakan oleh negara pada pembuat delik (Roeslan Saleh 1987: 17).

Dalam Pasal 10 KUHP ditentukan macam pidana pokok yang meliputi: pidana mati, penjara, kurungan dan denda. Terhadap seseorang yang terbukti telah melakukan perbuatan pidana, maka hakim dapat menjatuhkan salah satu dari pidana pokok tersebut. Penjatuhan pidana tersebut mempunyai suatu tujuan, yaitu menjerakan, membalas perbuatan pelaku maupun untuk tujuan pemidanaan.

Terlepas dari tujuan tersebut, untuk pemidanaan yang berupa pidana perampasan kemerdekaan badan (penjara, kurungan) ada beberapa dampak negatif yang sering dirasakan bagi narapidana, antara lain terampasnya kehidupan seksual, terampasnya kehidupan sosial ekonomi keluarganya, adanya cap/stigma jahat oleh masyarakat, penurunan derajad dan harga diri manusia.

Mengingat dampak tersebut, hakim dapat menjatuhkan pidana

Yustisia Vol.1 No.1 Januari - April 2012 selain yang ditentukan dalam Pasal 10 , yaitu berupa pidana bersyarat (pasal 14a KUHP). Dalam menjatuhkan pidana bersyarat, hakim harus memperhatikan beberapa hal, seperti syarat perbuatan yang dilakukan seseorang, hakim akan menjatuhkan putusan dengan pidana penjara atau kurungan paling lama 1 tahun, hakim telah menyelidiki dengan cermat bahwa ada pengawasan yang cukup terhadap terpidana bersyarat, kejahatan yang dilakukan bukan merupakan kejahatan berat, pelaku baru pertama kali melakukan perbuatan pidana, hakim menetapkan syarat umum atau syarat khusus selama kurun waktu tertentu (disebut masa percobaan) yang harus dipatuhi oleh terpidana. Adapun syarat umum adalah larangan terpidana untuk melakukan perbuatan pidana selama masa percobaan, sedangkan syarat khusus tidak selalu harus ditetapkan oleh hakim.

Bagi terpidana bersyarat, maka orang yang bersangkutan tidak perlu menjalani pidana yang dijatuhkan oleh hakim di lembaga pemasyarakatan (lapas), sehingga kemungkinan timbulnya dampak negatif dari pergaulan di lapas dapat dihindari.

Menurut Pasal $14 \mathrm{f}$ ayat (1) KUHP, apabila ada beberapa keadaan yang dilanggar selama masa percobaan, maka atas usul jaksa selaku pengawas pidana bersyarat, hakim yang memutus perkara dalam tingkat pertama dapat memerintahkan supaya pidananya dijalankan.

Mencermati persyaratan yang ditetapkan hakim dan harus dipatuhi

Pengawasan Terhadap Syarat... 104 
oleh narapidana bersyarat selama masa percobaan, tentunya harus ada pengawasan yang cukup oleh pihak yang bertugas mengawasi, supaya pidana itu dapat berdayaguna bagi terpidana. Untuk itu peneliti tertarik mengkaji pengawasan terhadap pelaksanaan syarat-syarat yang ditetapkan hakim, oleh petugas pengawas.

Berdasarkan latar belakang masalah yang sudah dipaparkan di atas, maka permasalahan yang diangkat dalam penelitian ini adalah bagaimana pelaksanaan pengawasan terhadap syarat umum dan khusus oleh pengawas putusan pidana bersyarat?

\section{B. Tinjauan Pustaka}

Pemidanaan yang dijatuhkan oleh lembaga pengadilan mempunyai suatu maksud atau tujuan. Dalam hukum pidana dikenal beberapa teori tujuan pemidanaan(Andi Hamzah, 1986: 17-22).

1. Teori pembalasan, yaitu bagi setiap pelaku perbuatan pidana harus dijatuhi pidana yang dianggap sebagi suatu pembalasan. Teori ini terbagi dua yaitu pembalasan subyektif dan pembalasan obyektif. Teori pembalasan subyektif yaitu pembalasan terhadap kesalahan pelaku, sedang teori pembalasan obyektif adalah pembalasan terhadap apa yang telah diciptakan oleh pelaku terhadap masyarakat.

2. Teori tujuan atau teori relative, yaitu maksud dari penjatuhan pidana adalah mencegah kejahatan dengan menakuti orang supaya tidak melakukan perbuatan pidana

Yustisia Vol.1 No.1 Januari - April 2012 (teori relatif umum), sedangkan menurut teori relatif khusus tujuan pemidanaan dimaksudkan agar pelaku menjadi jera. Lebih lanjut Van Hammel menerangkan suatu tujuan khusus dari suatu pidana, adalah adanya suatu unsur menakutkan supaya mencegah penjahat tidak melaksanakan niat buruknya, pidana harus mengandung unsur memperbaiki terpidana, pidana mempunyai unsur membinasakan penjahat yang tidak mungkin diperbaiki kelakuannya, dan untuk tujuan mempertahankan tertib masyarakat.

3. Teori gabungan, yaitu tujuan penjatuhan pidana adalah membalas kesalahan pelaku dan mengamankan masyarakat. Kedua tindakan ini dimaksudkan untuk mempersiapkan dan mengembalikan terpidana kembali ke masyarakat. Saat ini teori gabungan banyak diterapkan di berbagai Negara, termasuk di Indonesia yang diimplementasikan dalam Undang-Undang No 12 tahun 1995 tentang Pemasyarakatan sebagai pengganti Reglement Penjara, Stb 1917-708, tahun 1917.

Model kombinasi atau gabungan tujuan pemidanaan juga mulai diatur dalam Rancangan KUHP tahun 2006, yaitu :

1. Mencegah dilakukannya tindak pidana dengan menegakkan norma hukum demi mengayomi masyarakat

2. Mengadakan koreksi terhadap terpidana sehingga menjadi orang baik dan berguna serta mampu hidup bermasyarakat

Pengawasan Terhadap Syarat... 105 
3. Menyelesaikan konflik yang ditimbulkan oleh suatu tindak pidana, memulihkan keseimbangan dan mendatangkan rasa damai

4. Membebaskan rasa bersalah pada terpidana

Tujuan pemidanaan tersebut juga sesuai dengan The Fourth United Nations Congress on The Prevention of Crime and The Treatment of Offenders tahun 1970 di Kyoto, yang mencantumkan agenda pembicaraan tentang social defence politics in relation to development planning, yang berpandangan bahwa perlindungan masyarakat harus merupakan bagian integral dari perencanaan pembangunan (Bambang Poernomo, 1986: 225).

Menurut Ted Honderich yang dikutip Barda Nawawi, bahwa pemidanaan dapat menjadi alat pencegah kejahatan yang ekonomis apabila memenuhi beberapa syarat, yaitu, pidana tersebut dapat sungguhsungguh mencegah kejahatan, pidana tidak menyebabkan keadaan yang lebih berbahaya atau merugikan daripada apabila pidana tidak dijatuhkan, dan tidak ada pidana lain yang dapat mencegah secara efektif dengan biaya/kerugian yang lebih kecil (Barda Nawawi, 1996: 39).

Pemidanaan tidak selalu harus diterapkan dalam menanggulangi tindak pidana, tetapi menurut Nigel Walker yang dikutip Barda Nawawi, sarana penal ada prinsip-prinsip pembatasan, antara lain yaitu (Barda Nawawi, 1998; 48) :

1. Penggunaan hukum pidana tidak semata-mata dipergunakan sebagai sarana pembalasan
2. Hukum pidana tidak untuk memidana perbuatan yang tidak merugikan ataupun membahayakan

3. Hukum pidana tidak diterapkan untuk tujuan yang tidak efektif

4. Hukum pidana tidak digunakan apabila akan menimbulkan kerugian atau bahaya

Penjatuhan pidana kepada seorang pelaku perbuatan pidana tidak semata-mata ditujukan kepada orang yang terbukti bersalah tetapi juga perlu memperhatikan aspek lain yang dominan untuk dilindungi, yaitu ketertiban dan keamanan masyarakat. Karena kalau tujuan pertama yang diarahkan dalam penjatuhan pidana tetapi rasa keadilan masyarakat diabaikan, maka keseimbangan kehidupan masyarakat tidak akan terwujud.

Perlunya pendekatan humanistis dalam pengenaan sanksi pidana tidak hanya berarti, bahwa pidana yang ditimpakan kepada pelaku harus sesuai dengan nilai kemanusiaan, tetapi juga dapat membangkitkan kesadaran pelaku untuk berkelakuan lebih baik.

Penggunaan sanksi pidana merupakan suatu kebijakan dalam rangka menanggulangi kejahatan meskipun kejahatan itu tidak akan pernah lenyap dari muka bumi, karena sebenarnya faktor penyebab kejahatan sangatlah kompleks diluar jangkauan manusia, kejahatan merupakan masalah kemanusiaan sebagai masalah sosio-psikologis, sosio-politik, sosio-ekonomi, sosioklutural, penggunaan hukum pidana hanya merupakan pengobatan 
simptomatik bukan pengobatan kausatif.

Mencermati tujuan pemidanaan yang terdapat dalam Rancangan KUHP dan Ted Honderich, maka pemidanaan tidak selalu harus berarti suatu nestapa atau penderitaan dengan menempatkan terpidana dalam tempat khusus dan terisolir dari masyarakat, tetapi perlu memperhatikan pula aspek kesalahan, sosiologis, psikologis dari pelaku. Sehingga hakim dapat memilih untuk tidak menjatuhkan pidana perampasan kemerdekaan seseorang dengan memberikan suatu pidana bersyarat.

Pidana bersyarat yang didalam praktek biasa disebut dengan istilah pidana percobaan, dijatuhkan oleh hakim kepada pelaku perbuatan pidana dimaksudkan bukan sebagai suatu pembalasan, tetapi merupakan suatu usaha perbaikan perilaku seseorang.

Di dunia, dikenal dua sistem pidana bersyarat, yaitu :

1. Sistem Inggris-Amerika (Adami Chazawi, 2005: 55).

Menurut Sistem InggrisAmerika, terhadap seorang yang melakukan perbuatan pidana, apabila terbukti bersalah oleh hakim dinyatakan bersalah namun tanpa vonis pemidanaan kemudian ditetapkan suatu masa percobaan. Selama masa percobaan, pelaku diharapkan memperbaiki perilakunya serta harus mematuhi syarat-syarat tertentu yang ditetapkan oleh hakim dengan diawasi oleh lembaga pengawas tertentu. Sistem ini disebut dengan probation.

Apabila dalam masa percobaan, pelaku melanggar syarat yang

Yustisia Vol.1 No.1 Januari - April 2012 ditetapkan hakim, maka hakim barulah menjatuhkan pidana, sehingga dalam sistem ini yang digantungkan syarat adalah penjatuhan pidananya, bukan pelaksanaan pidana (Adami Chazawi, 2005; 56).

2. Sistem Belgia-Perancis,

Menurut sistem ini terhadap orang yang melakukan perbuatan pidana dan oleh pengadilan dinyatakan bersalah, hakim dapat menjatuhkan vonis berupa pidana bersyarat, dengan ketentuan selama kurun waktu tertentu (masa percobaan) pelaku harus mematuhi syarat tertentu, seperti larangan melakukan perbuatan pidana. Namun selama masa percobaan tersebut tidak ada pengawasan dari lembaga tertentu, seperti dalam sistem Inggris-Amerika.

Pelaksanaan pidana bersyarat di Indonesia menganut campuran dari dua sistem tersebut, yaitu terhadap pelaku yang terbukti bersalah dijatuhi vonis berupa pidana bersyarat (sistem Perancis-Belgia), dan selama kurun waktu tertentu harus mematuhi syarat-syarat yang ditetapkan hakim dengan diawasi oleh lembaga tertentu (sistem Inggris-Amerika). Adanya penetapan syarat umum oleh hakim adalah suatu keharusan atau bersifat imperatif, yaitu berupa larangan untuk melakukan suatu perbuatan pidana. Sedangkan penetapan syarat khusus sifatnya fakultatif, artinya hakim tidak harus menetapkan syarat tersebut kepada terpidana.

Apabila dibandingkan dengan pidana bersyarat yang diterapkan di Belanda, ada sedikit perbedaan, yaitu adanya syarat ancaman pidana dari

Pengawasan Terhadap Syarat... 107 
perbuatan yang dilakukan oleh terdakwa adalah pidana penjara antara 1 sampai 3 tahun (Barda Nawawi, 2004; 65).

Selama masa percobaan tersebut, narapidana bersyarat tidak hanya diawasi tetapi juga dilakukan pembimbingan. Pengawasan ini dilakukan oleh beberapa pihak, yaitu menurut Pasal 277 jo 278 KUHAP oleh hakim pengawas pengamat, pasal $14 \mathrm{~d}$ ayat (1) jo Pasal $30 \mathrm{UU}$ No 16 Tahun 2004 oleh jaksa dan menurut Pasal $14 \mathrm{~d}$ ayat (2) jo Pasal 1 ayat (9) Uu No 12 Tahun 1995 oleh BAPAS.

Kejaksaan selaku eksekutor putusan dalam melakukan pengawasan juga mendasarkan pada Surat Jaksa Agung No. B122/0/E/2/1982 yang dalam praktik melibatkan aparat pemerintah setempat.

Dalam Rancangan KUHP tahun 2006, pidana bersyarat ini juga di kenal, namun penyebutannya dengan pidana pengawasan. Pada Pasal 77, pidana pengawasan akan dikenakan kepada terdakwa apabila ia melakukan suatu perbuatan pidana yang diancam dengan pidana penjara paling lama 7 tahun, dengan mengingat keadaan dan perbuatannya dan untuk pembinaannya cukup diawasi (Barda Nawawi, 2008:199).

Bentuk pidana pengawasan yang terdapat dalam Konsep KUHP adalah suatu cara mempertahankan pidana penjara namun diimbangi dengan pembatasan dalam pelaksanaannya. Jenis pidana ini bersifat noncustodial, yaitu terpidana tidak dirampas kemerdekaannya dalam lembaga pemasyarakatan, atau di Inggris dikenal dengan istilah probation dan dalam KUHP disebut dengan pidana bersyarat.

\section{Metode Penelitian}

Data dalam penelitian ini berupa data primer dan sekunder. Data primer diperoleh langsung dari subyek penelitian dan dta sekunder diperoleh dari tidak langsung dari subyek penelitian. Penelitian dilakukan dengan teknik interview dengan interview guide. Pengambilan sampel dengan teknik non-random sampling, jenis sampling adalah purposive. Narasumber adalah Hakim PN Yogya yang pernah menjabat sebagai hakim pengawas pengamat putusan, jaksa pada Kejaksaan Negeri Yogya dan Kepala BAPAS Yogyakarata. Data sekunder diperoleh dari penelitian pustaka. Berupa peraturan undang-undang, Konsep KUHP Tahun 2006, bukubuku yang memberi penjelasan dan berkaitan dengan masalah yang diteliti. Semua data dianalisis secara deskriptif kualitatif.

\section{Hasil Penelitian dan Pembahasan}

1. Penjatuhan Pidana Bersyarat

Pemidanaan tidak selalu harus diterapkan dalam menanggulangi tindak pidana, tetapi menurut Niger Walker yang dikutip Barda Nawawi, sarana penal dapat dipergunakan dengan memperhatikan syarat-syarat, bahwa pemidanaan tidak sematamata sebagai sarana pembalasan, tidak untuk memidana perbuatan yang tidak merugikan, tidak untuk tujuan yang tidak efektif dan pemidanaan tidak menimbulkan kerugian.[6]

Pengawasan Terhadap Syarat... 108 


\begin{tabular}{llr}
\multicolumn{1}{c}{ Dalam } & pemidanaan, & teori \\
retributif & merupakan & teori \\
pemidanaan & yang tertua & yang \\
mendasarkan & bahwa bagi pelaku \\
tindak & pidana & harus \\
mempertanggungjawabkan &
\end{tabular}

perbuatannya dengan model pembalasan. Namun dalam perkembangannya teori tersebut mulai menerapkan model individualisasi pidana,[7] yang meliputi beberapa faktor, antara lain kondisi mental, macam perbuatan yang dilakukan, usia pelaku dan faktor lainnya yang berhubungan dengan sifat dan keadaan si pembuat. Sehingga dapat dikatakan bahwa teori pembalasan tersebut sudah mengarah pada teori pembalasan modern, yang mengartikan bahwa pembalasan bukanlah sebagai tujuan tersendiri tetapi harus ada keseimbangan antara perbuatan dan pidana.

Ide atau pemikiran mengenai individualisasi pidana tersebut juga mulai dimasukkan dalam Konsep KUHP dalam ketentuan umum Buku I, antara lain meliputi alasan penghapus pidana, adanya pedoman pemidaaan bagi hakim. Selain itu hakim juga perlu mempertimbangkan hal-hal yang dapat memperingan dan memperberat pidana, [8]

Perkembangan hukum pidana di Indonesia sudah mengarah pada dehumanisasi, yang di dalam penerapannya memperhatikan aspek resosialisasi dari pelaku tindak pidana, sehingga pidana yang dijatuhkan hakim tidak lagi sematamata dirasakan sebagai suatu penderitaan tetapi juga mempunyai nilai positif bagi pelaku.

Yustisia Vol.1 No.1 Januari - April 2012
Terlihat dari perkembangan pemidanaan tersebut antara lain dengan pengaturan pidana bersyarat yang sebenarnya tidak merupakan pidana pokok, tetapi merupakan cara penerapan pidana. Pidana bersyarat dimungkinkan akan dijatuhkan oleh hakim dengan terpenuhinya syarat-syarat sebagaimana yang telah ditentukan dalam Pasal 14a-14f KUHP.

Menurut ketentuan Pasal 14 a KUHP, pidana bersyarat akan dijatuhkan kepada terdakwa, dengan syarat hakim akan menjatuhkan pidana tidak lebih dari satu tahun. Kalau mencermati isi pasal tersebut, yang menjadi dasar penjatuhan pidana bersyarat bukanlah besarnya ancaman pidana, tetapi pidana atau hukuman yang akan dijatuhkan oleh hakim. Jenis pidana itupun tidak hanya terbatas pada pidana penjara, tetapi kurungan bahkan pidana denda. Menurut penjelasan Elfi Marzuni, hakim pada PN Yogyakarta, dalam praktek, hakim menjatuhkan pidana bersyarat tanpa melihat jenis perbuatan yang dilakukan terdakwa, tetapi mengacu pada persyaratan Pasal 14a diatas, sehingga dimungkinkan semua jenis perbuatan pidana dapat dijatuhkan pidana bersyarat.

Hakim juga mempertimbangkan kepribadian terdakwa. Hal itu dapat diketahui dari hasil penelitian kemasyarakatan yang dilakukan olehi Balai Pemasyarakatan (BAPAS). Apabila perilaku terdakwa dipandang baik, belum pernah melakukan perbuatan pidana atau belum pernah dihukum sebelumnya, maka hakim dapat

Pengawasan Terhadap Syarat... 109 
menjatuhkan pidana selain pidana perampasan kemerdekaan badan, yaitu pidana bersyarat.

Dalam hal ini hakim juga memperhatikan adanya pengawasan yang cukup bagi terpidana sekiranya pidana bersyarat tersebut akan dijatuhkan oleh hakim. Hal tersebut ditentukan secara tegas dalam Pasal 14 a ayat (4) KUHP. Lebih lanjut Elfi Marzuni juga menjelaskan, bahwa penjatuhan pidana bersyarat tetap mempunyai efek penjeraan bagi terpidana, karena hakim menetapkan syarat umum dan dapat juga menetapkan syarat khusus yang harus dipatuhi selama masa percobaan (MP) paling lama 2 tahun untuk pelanggaran dan untuk kejahatan 3 tahun. Selama MP terpidana diawasi oleh jaksa selaku eksekutor putusan dan BAPAS. BAPAS merupakan suatu lembaga yang ditunjuk oleh hakim untuk turut memberikan pengawasan dalam pelaksanaan syarat khusus dan memberi pembimbingan kepada terpidana bersyarat. Hal ini dilakukan oleh hakim sebagaimana termaktub dalam ketentuan Pasal 14 d ayat (2) KUHP yang memberi kemungkinan ditunjuknya suatu lembaga yang membantu tugas jaksa.

Dalam menetapkan syarat umum yang berupa larangan untuk tidak melakukan perbuatan pidana selama MP, oleh hakim akan diterapkan bagi semua terpidana, baik dewasa maupun anak, karena syarat umum ini merupakan syarat yang sifatnya imperatif. Adapun dalam menetapkan syarat khusus, hakim akan menyesuaikan dengan usia, keadaan pribadi, kedaan sosial, ekonomi dari pelaku. Karena sifat

Yustisia Vol.1 No.1 Januari - April 2012 syarat khusus ini adalah fakultatif, yang artinya hakim boleh menentukan, juga boleh tidak menentukan.

Untuk syarat khusus yang berupa pembayaran sejumlah ganti rugi kepada korban, menurut Pasal 14c KUHP dapat ditetapkan oleh hakim, apabila tindak pidana yang dilakukan pelaku menimbulkan kerugian bagi orang lain. Namun hal ini juga melihat kondisi ekonomi terdakwa apabila memugkinkan untuk dibebani dengan pembayaran ganti rugi, maka syarat khusus tersebut dapat ditetapkan oleh hakim. Sedangkan syarat khusus lain yang berupa kewajiban untuk lapor pada lembaga yang berwenang mengawasi, meskipun sifatnya fakultatif, dalam praktek, hal itu tetap diwajibkan bagi terpidana bersyarat dewasa.

Bagi terdakwa anak pengaturan pidana bersyarat mengacu pada Undang-Undang No. 3 Tahun 1997 tentang Pengadilan Anak. Dalam Pasal 29 ayat (1) ditentukan, bahwa pidana bersyarat dapat dijatuhkan kepada terpidana apabila pidana penjara yang dijatuhkan hakim paling lama dua tahun. Apabila kita perbandingkan persyaratan yang harus diperhatikan hakim dalam penjatuhan pidana bersyarat, maka jenis pidana yang dilakukan terdakwa anak hanya pidana penjara saja. Lama pidana yang akan dijatuhkan hakim tidak lebih dari 2 tahun. sedangkan masa pidana bersyarat paling lama tiga tahun.

Apabila memperhatikan perbedaan tersebut diatas, ternyata syarat bagi terdakwa anak untuk lamanya pidana yang akan

Pengawasan Terhadap Syarat... 110 
dijatukan hakim, lebih menguntungkan. Tetapi kalau mencermati jenis pidana yang boleh dijatuhkan hanya pidana penjara saja, nampaknya merupakan suatu kerugian. Namum kalau diperhatikan secara seksama, dalam UU 3 tahun 1997 menambahkan jenis pidana pengawasan yang merupakan salah satu macam pidana pokok. Untuk pelaksanaan pidana ini hampir sama dengan pidana bersyarat. Letak perbedaannya adalah pada putusan yang dijatuhkan hakim, yaitu pidana penjara atau kurungan paling singkat tiga bulan dan paling lama dua tahun.

Penentuan syarat khusus dan syarat umum untuk terdakwa anak merupakan suatu keharusan. Namun masa pidana bagi syarat khusus lebih pendek dari masa pidana bagi syarat umum. Berbeda dengan terdakwa dewasa yang hanya diharuskan menentukan syarat umum, sedangkan syarat khusus bersifat fakultatif. Ketentuan ini sepintas memberatkan, tetapi kalau dilihat dari tujuan penentuan syarat khusus yang berupa persyaratan untuk melakukan atau tidak melakukan hal tertentu yang ditetapkan hakim namun tetap memperhatikan kebebasan anak, maka justru akan menguntungkan anak. Disini terkandung pemeliharaan solidaritas sosial dalam bentuk partisipasi masyarakat yang turut membina narapidana bersyarat, yang dalam hal ini dilakukan oleh suatu lembaga (BAPAS). Selain dari BAPAS, jaksa juga turut melakukan pengawasan terhadap narapidana bersyarat anak.

Yustisia Vol.1 No.1 Januari - April 2012
Dalam menjatuhkan pidana kepada terdakwa anak, termasuk pidana bersyarat, hakim harus mempertimbangkan hasil penelitian masyarakat (litmas) yang dilakukan oleh BAPAS, seperti keadaan pribadi terdakwa, keadaan keluarga, lingkungan. Apabila hasil Litmas menunjukkan bahwa perilaku terdakwa baik, kondisi keluarga dan lingkungan mendukung dan memungkinkan dalam memberikan pendidikan dan suport kepada terdakwa, pidana bersyarat merupakan bentuk pemidanaan yang tepat yang akan dijatuhkan bagi anak.

Penjatuhan pidana bersyarat akan bermanfaat bagi terpidana. Keuntungan yang pertama adalah menyelamatkan narapidana dari penderitaan pidana pencabutan kemerdekaan, dan itu akan membawa dampak bagi perlindungan masyarakat akan kemungkinan munculnya penjahat yang lebih berat. Hal demikian bisa terjadi karena terpidana akan terhindar dari pergaulan yang negatif dengan sesama narapidana yang akan berdampak bagi perkembangan perilaku.

Beberapa negara telah memikirkan untuk mencari alternatif dari pidana pencabutan kemerdekaan. Hal ini juga menjadi pembahasan dalam Konggres PBB ke-6 tahun 1980 di Caracas mengenai The Prevention of Crime and The Treatment of Offenders dengan topik Deinstitutionalization of corrections. Namun pidana pencabutan kemerdekaan juga tidak dapat begitu saja dihapuskan, meskipun sebenarnya dari segi tujuan ada hal-

Pengawasan Terhadap Syarat... 111 
hal yang saling bertentangan atau ambivalensi, yaitu :

1. Tujuan pidana penjara adalah menjamin pengamanan narapidana dan memberikan kesempatan narapidana untuk direhabilitasi

2. Hakekat fungsi penjara sering mengakibatkan dehumanisasi pelaku yang kemudian akan menimbulkan kerugian karena pelaku tidak dapat melakukan kegiatan produktif dalam masyarakat

Keuntungan lain yang dirasakan oleh terpidana adalah, mereka tetap dapat melakukan kegiatan rutin seperti biasanya. Hakim akan menjatuhkan pidana bersyarat terhadap terdakwa anak maupun terdakwa dewasa, dengan dasar alasan, mereka dapat melakukan aktivitas atau kegiatan rutin seperti ketika mereka belum dijatuhi pidana bersyarat. Bagi anak, kegiatan belajar tetap dapat mereka ikuti walau mereka diputus bersalah dan dijatuhi pidana. Bagi terpidana dewasa, kalau ia seorang kepala keluarga, maka sebagai kepala rumah tangga yang bertugas mencari nafkah, kegiatan tersebut tetap dapat dilaksanakan.

2. Pelaksanaan dan Pengawasan Narapidana Bersyarat.

Dalam pelaksanaan syarat umum dan syarat khusus bagi narapidana bersyarat, Pasal $14 \mathrm{~d}$ ayat (1) KUHP menentukan, bahwa pengawas dari narapidana adalah pejabat yang bertugas mengawasi pelaksanaan putusan. Adapun petugas yang dimaksud oleh ketentuan diatas adalah jaksa selaku eksekutor putusan. Disamping itu dalam Pasal 30 ayat (1) huruf c Undang-Undang no 16 Tahun 2004

Yustisia Vol.1 No.1 Januari - April 2012
Tentang Kejaksaan juga ditentukan, bahwa jaksa memiliki tugas melakukan pengawasan narapidana bersyarat.

Dalam melakukan pengawasan tersebut jaksa dibantu oleh BAPAS. Penunjukan lembaga lain dalam melakukan pengawasan memang dimungkinkan, karena Pasal 1 d ayat (2) KUHP mengamanatkan hal tersebut. Lembaga BAPAS merupakan lembaga yang berada dibawah koordinasi Kementerian Hukum dan HAM. Berdasar ketentuan Pasal 277 jo Ps 280 KUHAP, hakim pengawas pengamat (kimwasmat) tidak hanya mengawasi putusan yang berupa pidana pokok tetapi juga pidana bersyarat.

Seorang hakim pengawas dan pengamat mempunyai tugas untuk mengetahui apakah putusan yang sudah dijatuhkan oleh hakim sudah dijalankan sebagaimana mestinya oleh eksekutor putusan, Kemudian perlu ada pengamatan lebih lanjut terhadap perilaku narapidana selama menjalani putusan baik di dalam lembaga pemasyarakatan, rumah tahanan maupun diluar lembaga. Pemberian pembinaan oleh petugas pemasyarakatan juga menjadi bahan pengamatan dari kimwasmat. Karena pemberian putusan dan pembinaan tersebut terkandung maksud tidak hanya semata-mata memberikan pembalasan bagi pelaku tetapi yang lebih utama adalah kemanfataan dari pemidaan tersebut. Hal itu dapat dilihat dari perubahan perilaku yang positif si narapidana.

Hakim pengawas dan pengamat dapat dikatakan sebagai "cabang" dari pengadilan. Di Perancis dikenal

Pengawasan Terhadap Syarat... 112 
dengan istilah application des peines, suatu lembaga yang bertugas sesudah putusan dijatuhkan, bahkan setelah orang yang dipidana selesai menjalani hukuman. Hakim sebagai pejabat yang memutus perkara pidana tidak hanya berhenti pada saat putusan dijatuhkan, tetapi juga bertanggungjawab atas putusan tersebut. Hakim harus mengetahui apakah putusan yang dijatuhkan kepada terpidana sudah dijalankan sesuai asas perikemanusiaan dan keadilan oleh petugas serta apakah putusan tersebut membawa manfaat bagi pelaku sehingga menjadi anggota masyarakat yang baik.

Dalam kenyataan fungsi pengawasan dari Kimwasmat tidak efektif berjalan. Karena disetiap wilayah pengadilan negeri hanya ditunjuk seorang hakim pengawas pengamat yang harus melaksanakan tugas pengawasan untuk berbagai putusan yang jumlahnya tidak sedikit dan tugas tersebut akan diemban selama 2 tahun. Kimwasmat hanya melakukan pemantauan ke lembaga pemasyarakatan setiap tiga bulan sekali, atau setiap enam bulan, hasilnya kemudian dilaporkan kepada ketua pengadilan negeri yang membawahi wilayah hukum lapas tersebut. Menurut penjelasan Elfi Marzuni, hakim pengawas pengamat harus mengeluarkan biaya sendiri untuk melakukan kunjungan pengawasan ke lembaga pemasyarakatan. Hal ini juga merupakan suatu kendala bagi kimwasmat dalam menjalankan tugasnya.

Sebenarnya maksud dari pembentuk undang - undang

Yustisia Vol.1 No.1 Januari - April 2012 menugaskan hakim untuk melakukan pengawasan tidak hanya untuk mengetahui ketepatan putusan pemidanaan bagi pelaku saja tetapi juga kemanfaatan bagi pemidanaan pada umumnya.

Dalam pelaksanaannya, fungsi pengawasan lebih banyak dilakukan oleh BAPAS. Sebenarnya tugas utama dari BAPAS adalah memberikan pembimbingan bagi klien pemasyarakatan, namun karena pembimbingan tersebut dilakukan secara rutin dan teratur, sehingga BAPAS dianggap mampu pula untuk melakukan pengawasan kepada narapidana bersyarat. Adapun model pembimbingan dilakukan dengan cara, narapidana datang ke kantor BAPAS sekaligus melakukan pelaporan, atau narapidana diminta untuk datang di suatu tempat/lembaga yang diminta membantu melakukan pembimbingan.

Bentuk pengawasan dan pembimbingan yang dilakukan BAPAS merupakan realisasi dari model yang dianut Indonesia dalam penjatuhan pidana bersyarat. Indonesia menganut campuran dari Sistem Inggris-Amerika dan Sistem Perancis-Belgia, dimana perbuatan yang dilakukan oleh terdakwa terbukti bersalah, hakim menjatuhkan satu putusan pemidanaan tetapi tidak perlu dijalani didalam lapas atau rutan. Terhadap terp;idana akan diawasi dan dibimbing oleh lembaga yang ditunjuk oleh pemerintah.

Menurut Pasal 1 ayat (9) Undang-Undang No 12 Tahun 1995 Tentang Pemasyarakatan, tugas pembimbingan BAPAS yang

Pengawasan Terhadap Syarat... 113 
ditujukan kepada klien pemasyarakatan antara lain meliputi : narapidana (napi) bersyarat, napi yang mendapatkan pelepasan bersyarat, napi yang mendapat cuti menjelang bebas, napi yang mendapat cuti bersyarat, bimbingan lanjutan (after care).

BAPAS klas I Yogyakarta, sejak berdirinya pada tahun 1970 membawahi semua wilayah hukum pengadilan negeri se DIY. Namun sejak tahun 2003, setelah berdirinya BAPAS Klas II Wonosari, wilayah hukum BAPAS Yogyakarta hanya meliputi Pengadilan Negeri Yogyakarta, Sleman dan Kulonprogo. Untuk Pengadilan Negeri Bantul menjadi kewenangan dari BAPAS Wonosari. Adapun pembimbing kemasyarakatan BAPAS Yogyakarta saat ini berjumlah 26 orang. Dan dua orang pembimbing kemasyarakatan pembantu.

Pembimbingan terhadap klien pemasyarakatan dilakukan dengan beberapa tahapan. Untuk tahap pertama petugas akan melakukan identifikasi masalah klien, dalam tahap ini petugas akan mempelajari kondisi sosial, latar belakang kehidupan klien, keluarga, faktor penyebab pelaku melakukan perbuatan pidana, kemudian dilanjutkan dengan penentuan program pembimbingan. Hal ini dilakukan oleh petugas, karena terhadap setiap klien, pemberian pembimbingan akan disesuaikan dengan keadaan dan kondisi setiap person. Sehingga bimbingan yang diberikan diharapkan dapat memberi manfaat yang lebih baik bagi perkembangan dan kemajuan

Yustisia Vol.1 No.1 Januari - April 2012 perilaku klien. Untuk tahap ketiga adalah pelaksanaan program.

Adapun bentuk pembimbingan kepada klien pemasyarakatan meliputi bimbingan mental dan ketrampilan. Dalam melakukan pembimbingan sekaligus pengawasan BAPAS dapat melakukan kerjasama dengan lembaga pemerintah, lembaga swasta atau organisasi sosial. Menurut penjelasan Subagya, Kepala BAPAS Yogya, kerjasama tersebut dilakukan, karena mengingat jumlah pembimbing kemasyarakatan yang berjumlah 26 orang, dirasakan tidak dapat melakukan pembimbingan secara komprehensif terhadap seluruh kilen pemasyarakatan yang setiap bulannya berjumlah tidak kurang dari 100 orang.

Disamping itu tidak semua pembimbing kemasyarakatan menguasai berbagai bimbingan ketrampilan dan mental. Dengan adanya pembimbingan dari lembaga yang mempunyai keahlian khusus di bidangnya, maka pembinaan tersebut diharapkan akan membawa hasil yang optimal bagi kemajuan klien.

Sejak beberapa tahun silam, BAPAS Yogyakarta sudah melakukan kerjasama dengan beberapa insatansi pemerintah maupun swasta, antara lain kerjasama dengan Poltabes Yogyakarta yang memberikan bimbingan mental dengan materi penyalahgunaan narkoba, penyuluhan penyakit HIV dari Yayasan Kembang Yogyakarta, bimbingan ketrampilan budidaya ikan dari Dinas Pertanian dan Kehutanan Sleman, ketrampilan

Pengawasan Terhadap Syarat... 114 
membatik, merias, memasak dan menjahit dari Aisyiyah Cabang Kraton Yogyakarta.

Kerjasama dengan instansi lain tidak hanya sebatas pemberian ketrampilan, tetapi sering dilanjutkan dengan pemberian bantuan bahan, alat maupun modal kerja, seperti bantuan benih ikan, pakan ikan, mesin jahit dan peralatan menjahit. Pada tahun 2009, Departemen Sosial memberikan bantuan modal sebesar Rp 500.000,- setiap klien, dan pada tahun 2010 meningkat menjadi Rp. 1.000.000,-, sebanyak 20 klien. Jumlah klien BAPAS selama satu setengah tahun terakhir dapat dilihat pada tabel di bawah ini.

Tabel 1

Data Bimbingan Klien Pemasyarakatan Anak \& Dewasa BAPAS Klas I Yogyakarta Tahun 2009

\begin{tabular}{|c|l|c|c|c|}
\hline No & STATUS KLIEN & ANAK & DEWASA & JUMLAH \\
\hline 1 & Pidana Bersyarat (PIB) & 12 & 37 & 49 \\
\hline 2 & Pembebasan Bersyarat & 4 & 113 & 117 \\
\hline 3 & Cuti Menjelang Bebas & 2 & 28 & 30 \\
\hline 4 & Cuti Bersyarat & 18 & 159 & 177 \\
\hline 5 & Bimbingan Lanjutan & 1 & 17 & 18 \\
\hline
\end{tabular}

Sumber : BAPAS Yogyakarta 2009

Dari tabel diatas dapat diketahui bahwa jumlah klien pemasyarakatan selama satu tahun, yang mendapatkan hukuman pidana bersyarat sebanyak 49 orang ( meliputi tiga wilayah pengadilan

Tabel 2

Data Bimbingan Klien Pemasyarakatn Anak \& Dewasa

BAPAS Klas I Yogyakarta

Per 25 Agustus 2010

\begin{tabular}{|c|l|c|c|c|}
\hline No. & STATUS KLIEN & ANAK & DEWASA & JUMLAH \\
\hline 1 & Pidana Bersyarat (PIB) & 9 & 21 & 30 \\
\hline 2 & Pembebasan Bersyarat & 2 & 94 & 96 \\
\hline 3 & Cuti Menjelang Bebas & - & - & - \\
\hline 4 & Cuti Bersyarat & 7 & 31 & 38 \\
\hline
\end{tabular}

Sumber : BAPAS Yogyakarta 2010 
Jumlah klien pidana bersyarat selama bulan Januari hingga Agustus 2010 mencapai 30 orang, kesemuanya ini juga terdiri dari tiga wilayah hukum pengadilan negeri (Kota Yogya, Kulonprogo dan Sleman). Rekap data dilakukan setiap 6 bulan, sehingga data bulan September sampai Desember 2010 belum diperoleh ketika penelitian dilakukan.

Pengawasan yang dilakukan oleh BAPAS, selain adanya kewajiban melapor satu minggu sekali, petugas kemasyarakatan BAPAS juga melakukan home visite ke rumah narapidana setiap bulan, untuk melakukan cross check, dengan tujuan untuk mengetahui perkembangan pembimbingan secara langsung. Tindakan ini juga merupakan satu bentuk pengawasan langsung bagi narapidana/klien pemasyarakatan dalam pelaksanaan syarat khusus sekaligus syarat umum. Karena yang dilakukan pembimbing kemasyarakatan tidak hanya mendatangi orang tua, keluarga, walinya, tetapi juga meminta keterangan dari pengurus kampung setempat. Sehingga petugas dapat mengetahui keadaan yang sebenarnya dari klien.

3. Pelanggaran Syarat oleh Narapidana Bersyarat

Menurut Subagya ( Kepala BAPAS Yogyakarta) pelanggaran syarat umum oleh napi bersyarat selama 2 tahun terakhir (2009, 2010) tidak pernah ada, sedangkan pelanggaran syarat khusus yang berupa kewajiban lapor, pernah ada, tetapi setelah dilakukan pendekatan dan diberi peringatan, napi tersebut kembali patuh dalam melakukan pelaporan. Pelanggaran tersebut tidak mempengaruhi pidana bersyarat, artinya napi tidak perlu menjalani pidananya dalam lapas. Apabila pelanggaran mengenai syarat khusus sudah berlebihan, seperti tidak melaporkan diri, lebih dari 3 kali, tidak mengikuti pembimbingan yang dijadwalkan petugas tanpa alasan yang sah, lebih dari tiga kali, oleh BAPAS hal tersebut dilaporkan kepada jaksa pengawas. Demikian juga apabila klien melakukan pelanggaran syarat umum, apabila BAPAS mengetahui hal tersebut, maka akan dilaporkan kepada jaksa.

Pasal $14 \mathrm{f}$ ayat (1) KUHP menentukan, apabila terjadi pelanggaran yang diketahui oleh jaksa, maka atas usul jaksa pengawas, hakim yang memutus pada tingkat pertama dapat memerintahkan supaya pidananya dijalani oleh pelaku. Tetapi yang terjadi dalam praktek, menurut penjelasan Elfi Marzuni, perintah untuk menjalankan pidana bersyarat mutlak menjadi kewenangan jaksa. Hakim hanya memutus pidananya saja, ada tidaknya pelanggaran, perlu tidaknya perintah untuk menjalankan putusan, hakim sudah lepas tangan dengan persoalan tersebut. Hal tersebut berkaitan dengan adanya persyaratan, hakim yang memerintah adalah hakim yang memutus pada tingkat pertama. Disini timbul kesulitan, karena tidak sedikit perkara untuk dapat dieksekusi memakan waktu lama, karena para pihak banyak yang melakukan upaya hukum baik upaya hukum biasa maupun upaya 
hukum luar biasa terhadap putusan perkaranya.

Sementara itu mutasi hakim di lingkungan pengadilan negeri sering terjadi dan rata-rata hakim bertugas di suatu pengadilan negeri hanya selama dua tahun, sehingga dimungkinkan hakim yang pernah memutus pidana bersyarat, ketika terjadi pelanggaran syarat umum, sudah berpindah tempat tugas.

Sedangkan menurut penjelasan Rendy, Jaksa pada Kejaksaan Negeri Yogyakarta, pada kenyataannya sangat sulit untuk melakukan pengawasan terhadap pelanggaran syarat-syarat oleh narapidana yang mendapat pidana bersyarat. Karena pengawasan yang dilakukan oleh jaksa sifatnya pasif, tidak seperti pengawasan yang dilakukan oleh petugas BAPAS. Selain itu, tidak ada koordinasi yang baik antar jaksa dari beberapa wilayah hukum kejaksaan negeri, sehingga kalau terjadi pelanggaran syarat umum, tidak dapat diketahui oleh jaksa pengawas.

Namun apabila selama masa percobaan diketahui napi melakukan perbuatan pidana yang artinya melakukan pelanggaranan syarat umum, baik informasi itu berasal dari BAPAS, dari penyidik ataupun masyarakat, maka pidana bersyarat dapat segera dijalankan.

\section{E. Penutup}

Pengawasan atas pelaksanaan syarat-syarat yang ditetapkan hakim terhadap napi bersyarat, dalam praktek dilakukan BAPAS. Sedangkan pengawasan yang seharusnya dilakukan oleh Hakim Pengawas Pengamat tidak dapat berjalan efektif, karena untuk mengawasi seluruh putusan perkara pidana hanya diserahkan kepada satu orang hakim untuk satu wilayah pengadilan negeri. Pengawasan yang dilakukan oleh pembimbing kemasyarakatan dari BAPAS tidak hanya pada pelaksanaan syarat khusus, juga termasuk syarat umum yang seharusnya menjadi tugas kimwasmat dan jaksa. Supaya tujuan dari pemidanaan dapat tercapai secara optimal, peneliti merekomendasikan agar pengawasan terhadap pidana bersyarat dilakukan secara bersinergi oleh kimwasmat, jaksa dan BAPAS. 


\section{Daftar Pustaka}

Adami Chazawi. 2005. Pelajaran Hukum Pidana., Jakarta: Raja Grafindo Persada

Barda Nawawi. 1996. Kebijakan Legislatif dalam Penanggulangan Kejahatan dengan Pidana Penjara. Semarang: Badan Penerbit UNDIP

Barda Nawawi. 1998. Beberapa Aspek Kebijakan Penegakan dan Pengembangan Hukum Pidana. Bandung: Citra Aditya Bakti

Barda Nawawi. 2008. Bunga Rampai Kebijakan Hukum Pidana. Jakarta: Kencana

Muladi. 1995. Lembaga Pidana Bersyarat. Bandung: Alumni

Muladi dan Barda Nawawi Arief. 1998. Teori-teori dan Kebijakan Pidana. Bandung : Alumni

Muladi dan Barda Nawawi. 1998. Alumni: Teori dan Kebijakan Pidana

Roeslan Saleh 1987. Stelsel Pidana Indonesia. Jakarta : Aksara Baru

Peraturan Pemerintah No 58 tahun 2010 tentang Perubahan atas PP No 27 Tahun 1983 tentang Pelaksanaan KUHAP. Jakarta: Departemen Kehakiman Republik Indonesia 